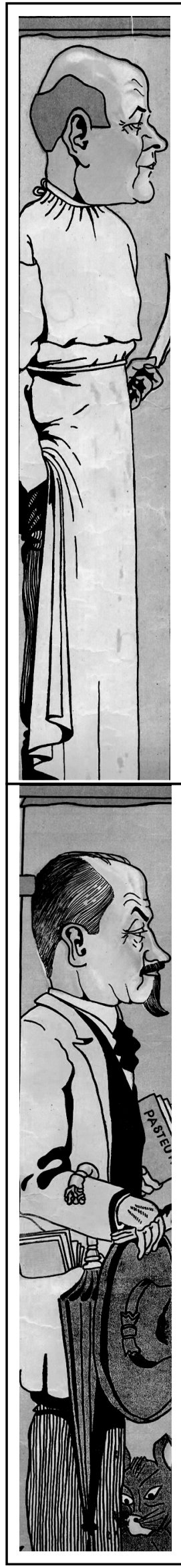

\title{
OAMENI DE SEAMĂ AI LUMII MEDICALE ROMÂNEŞTI
}

\section{PROFESOR DR. DOCENT ION MUREŞAN (1898-1983)} 1898.

Ion Mureşan s-a născut în Sanislău, județul Satu Mare, în

A absolvit Facultatea de Medicină din Cluj, făcând parte din primele generații de studenți de la înființarea ei. Dobândeşte titlul de doctor în 1925. Este preparator la Institutul de Anatomie Patologică apoi asistent şi şef de lucrări la Clinica chirurgicală sub îndrumarea profesorilor I.Iacobovici şi A.Popp, între 1926 şi 1936.

În 1936 obține prin concurs postul din cadrul serviciului de chirurgie al Spitalului de Stat din Timişoara.

In 1935 propune o soluție pentru o malformație-fanta mare palatină, prin croirea la distanță a unui lambou pediculat, implantat la buza superioară, în al doilea timp detaşând lamboul şi aplicându-l pe fanta palatină. De asemenea a avut lucrări de pionierat în chirurgia tiroidei.

A urmat cursuri de perfecționare la clinici din München (Lexner), Köln (von Haberer), Londra (Handley), Paris (Pauchet, Hartmann).

Odată cu înființarea Facultății din Timişoara în 1945 este numit profesor. A scris numeroase lucrări de specialitate şi tratate, fiind dascălul multor nume mari ale chirurgiei româneşti.

Se stinge din viață în 1983.

\section{dr. Bumbuluț Călin}

Bibliografie:

1. SETLACEC, D: Medicina românească-medicină europeană 19181940, ed Humanitas 1998, p. 198

2. CALOGHERA, C: Profesorul Dr. Doc. I.Mureşan (1898-1983), în Timişoara Medicală XXXIII, Nr 2,1988, p. 107-114 